\title{
Characterization of linear-oblong pyrenoids with cp-DNA along their sides in Nitzschia sigmoidea (Bacillariophyceae)
}

\author{
Shigeki Mayama, ${ }^{*}$ Nagisa Mayama and Ikuko Shihira-Ishikawa ${ }^{\dagger}$ \\ Department of Biology, Tokyo Gakugei University, Koganei-shi, Tokyo 184-8501, Japan
}

\section{SUMMARY}

In the past 10 years Nitzschia sigmoidea (Nitzsch) W. $\mathrm{Sm}$. has begun to occur in Japanese rivers in various areas. It is a common diatom in Europe but was previously absent in Japan. Each chloroplast of $N$. sigmoidea contains many unusual linear-oblong structures. The internal structure of the chloroplast in this species was observed using epifluorescence and electron microscopy with immunolocalization techniques. The linear-oblong structures in the chloroplasts could hardly be observed by conventional light microscopy of living cells, but were obvious in cells stained with propionocarmine. Transmission electron microscopy showed that the cross sections of this structure were lanceolate to fusiform with penetration by a single thylakoid. In cells stained with DAPI, chloroplast DNA was detected along both sides of the linear-oblong structures, and DNA fibrils were detected by electron microscopy. Immunofluorescence microscopy of sectioned cells and also immunoelectron microscopy revealed specific localization of Rubisco between these DNA-containing areas, which divided at the same time as the chloroplast. Our observations confirmed that the linear-oblong structures are pyrenoids. The diversity of localization patterns of chloroplast DNA in diatoms is discussed.

Key words: Bacillariophyceae, chloroplast DNA, chloroplast nucleoid, diatom, immunoelectron microscopy, immunofluorescence microscopy, Nitzschia sigmoidea, pyrenoid, Rubisco.

\section{INTRODUCTION}

After their initial description by Schmitz (1882), the pyrenoids of diatoms were frequently reported upon until the early 20th century (e.g. Schmitz 1884; Lauterborn 1896; Mitrophanow 1898; Karsten 1899; Mereschkowsky 1902). These researchers mainly observed the pyrenoids by staining, and described the shapes and the numbers in dozens of species. After publication of a review by Heinzerling (1908), however, the pyrenoids and even the chloroplasts of the diatoms did not attract much attention, and more recent reports on pyrenoids have been very few. Geitler
(1926, 1959, 1981) was one researcher who continued to investigate the pyrenoids, classifying them morphologically and discussing the systematics of both chloroplasts and pyrenoids. Tschermak-Woess (1953) noted the diversity of pyrenoids in some naviculoid species, Cox (1996) corroborated the usage of chloroplasts in identification of live diatoms, Mann (1996), who gave a comprehensive review of chloroplasts and pyrenoids in diatoms, discussed the importance of these investigations, and Schmidt (2001) restressed the value of pyrenoids in diatom systematics using stained cells and/or electron microscopy in 15 genera.

Most diatoms have only one pyrenoid per chloroplast, although knowledge of multiple pyrenoids has been accumulated little by little from a huge number of diatom species, for example, some species of Donkinia, Gyryosigma, Surirella, Toxonidea and Entomoneis (see Mann 1996; Schmidt 2001). It is known that the larger species tend to have several or many pyrenoids in general, and this trend can be seen within even a genus (Mann 1996). Whereas Nitzschia palea (Kütz.) W. Sm. is a small-celled species and has one pyrenoid per chloroplast (Geitler 1975), Nitzschia sigmoidea is a large-celled species and has many linear-oblong structures scattered throughout the chloroplasts (Geitler 1937). These structures were found in unstained cells and were also called pyrenoids.

Most pyrenoids have a smooth surface but some have characteristic invaginations as seen in Caloneis amphisbaena (Bory) Cleve (Tschermak-Woess 1953; Thaler 1972) and Sellaphora bacillum (Ehrenb.) D. G. Mann (under the name of Navicula bacillum, Mann 1984).

Transmission electron microscopy (TEM) has revealed the fine structure of the chloroplast with the pyrenoid in various diatom species. In profile view, many pyrenoids are lanceolate or semi-lanceolate to fusiform (e.g. Drum 1963; Drum et al. 1966; Manton et al. 1969; Crawford et al. 1981; Archibald \& Barlow 1983;

* To whom correspondence should be addressed.

†Present address: 60-2-606, Kamiishihara 3, Chofu-shi, Tokyo 182-0035, Japan.

Email: mayama@u-gakugei.ac.jp

Communicating editor: K. Okuda.

Received 5 June 2003; accepted 30 November 2003. 
Edgar \& Pickett-Heaps 1983; Li \& Volcani 1985), but are sometimes circular, rectangular or polyhedral (e.g. Drum et al. 1966; Coombs et al. 1968; Dawson 1973).

Drum and Pankratz (1964), who focused on the pyrenoid structure, showed several variations in several diatom species, and Edgar (1980) confirmed a pyrenoid with many invaginations in C. amphisbaena ultrastructurally.

Membrane-limited pyrenoids were also unique structures in some diatoms (Drum \& Pankratz 1964; Crawford 1973), though this fact does not appear to be a well-known pyrenoidal characteristics of diatoms, being confirmed in N. sigmoidea (Schmidt 2001).

It is evident in many algae that the ribulose-1,5bisphosphate carboxylase/oxygenase (Rubisco) protein is localized in the pyrenoid. Rubisco, as a major component of the pyrenoid, has been isolated from Micromonas squamata Manton et Parke (Salisbury \& Floyd 1978), Chlamydomonas reinhardtii Dangeard (Kuchitsu et al. 1988), Bryopsis maxima Okamura (Satoh et al. 1984) and Pilayella littoralis (L) Kjellm. (Kerby \& Evans 1978). The localization of Rubisco in the pyrenoid has also been shown by immunoelectron microscopy in Chlamydomonas (Lacoste-Royal \& Gibbs 1987; Morita et al. 1997), Chroomonas sp., Hemiselmis brunnescens Butcher (McKay et al. 1992) and Euglena gracilis G. A. Klebs (Osafune et al. 1990).

Detection of Rubisco in diatoms has been reported in Phaeodactylum tricornutum Bohlin by immunoelectron microscopy using anti-Rubisco antisera prepared from Olisthodiscus luteus N. Carter (Raphidophyceae) (McKay \& Gibbs 1991) and Isochrysis galbana Parke (Prymnesiophyceae) (Jenks \& Gibbs 2000). Orellana and Perry (1995) employed immunofluorescence microscopy to quantify Rubisco in single cells of several diatoms. The photographs they presented, however, did not show clearly where Rubisco was localized in the chloroplast.

In the present study, we found unusual linear structures in each chloroplast of $N$. sigmoidea, using light and electron microscopy, and confirmed them to be pyrenoids because of the accumulation of Rubisco in them. The pyrenoids were accompanied by chloroplast (cp) DNA outside. This specific structure of pyrenoid in $N$. sigmoidea was investigated.

\section{MATERIALS AND METHODS}

\section{Nitzschia sigmoidea}

The cells examined were isolated from the benthic diatom communities of the Koma River, Saitama Prefecture, and the Yoro River, Chiba Prefecture, in Japan. Methods of cell cleaning, washing and preparing objects for light microscopy are given in Kobayasi and Mayama (1982).

\section{Pyrenoid staining}

After fixation in an acidified hypochlorite solution, the cells were washed in ethanol and mixed with ferric propionate, followed by staining with propionocarmine (Rosowski \& Hoshaw 1970). The specimens were heated and washed with propionic acid, then observed with a light microscope.

\section{Detection and confirmation of DNA}

Cells fixed with $1 \%$ glutaraldehyde were stained with a mixture of $5 \mu \mathrm{g} / \mathrm{mL}$ 4'6-diamidino-2-phenylindole (DAPI) dissolved in distilled water and buffer-S (Nishibayashi \& Kuroiwa 1982) and observed with an Olympus $\mathrm{BH} 2$ RFK epifluorescence microscope (Olympus, Tokyo, Japan). For confirmation of DNA, $13 \mathrm{U} / \mathrm{mL}$ of DNase I (Type IV; Sigma, St Louis, MO, USA) dissolved in $0.08 \mathrm{~mol} / \mathrm{L}$ sodium acetate $(\mathrm{pH} 5.0), 4 \mathrm{mmol} / \mathrm{L} \mathrm{MgSO}_{4}$ and $0.025 \mathrm{~mol} / \mathrm{L} \mathrm{NaCl}$ was applied to the specimens, followed by incubation at $37^{\circ} \mathrm{C}$ for $3 \mathrm{~h}$.

\section{Indirect immunofluorescence microscopy}

For technovit sections, the cells were fixed with $1 \%$ glutaraldehyde, then embedded in an agar block. This block was dehydrated and embedded in Technovit 7100 resin (Heraeus Kulzer, Wehrheim, Germany) according to the manufacturer's instructions (Kuroiwa 1991). Thin sections of $0.5-1 \mu \mathrm{m}$ were cut with a glass knife on an ultramicrotome. These were affixed to slide glasses coated with poly-D-lysine hydrobromide, and etched for $30 \mathrm{~min}$ at $20^{\circ} \mathrm{C}$ with $125 \mathrm{mg} / \mathrm{mL}$ $\mathrm{NaIO}_{4}$, then incubated for $15 \mathrm{~min}$ in $0.5 \mathrm{mg} / \mathrm{mL}$ $\mathrm{NaBH}_{4}$, followed by rinsing in phosphate-buffered saline (PBS) for $30 \mathrm{~min}$. Sections were incubated for $10 \mathrm{~min}$ in blocking solution ( $5 \%$ bovine serum albumin $(B S A)$ ), then rinsed in PBS containing 0.05\% Tween20 for $10 \mathrm{~min}$. Subsequently, they were immunolabeled for $1 \mathrm{~h}$ at $37^{\circ} \mathrm{C}$ with an antibody raised against the large subunit of Rubisco purified from cucumber (Ohya \& Shimazaki 1989). After rinsing in PBS for $30 \mathrm{~min}$, followed by treatment with PBS containing $0.05 \%$ Tween-20 for $10 \mathrm{~min}$, they were incubated with fluorescein isothiocyanate (FITC)-conjugated goat antirabbit IgG (Sigma) diluted $1: 3$ in PBS containing $1 \%$ $\mathrm{BSA}$ at $37^{\circ} \mathrm{C}$ for $1 \mathrm{~h}$. Specimens that had been rinsed in PBS and then in distilled water were then stained with DAPI and observed with an Olympus BH2-RFK epifluorescence microscope. A control for the immunofluorescence was prepared by omitting the primary antibody, and specific staining of the pyrenoids could not be detected, though slight non-specific staining was observed in frustules and nuclei. 


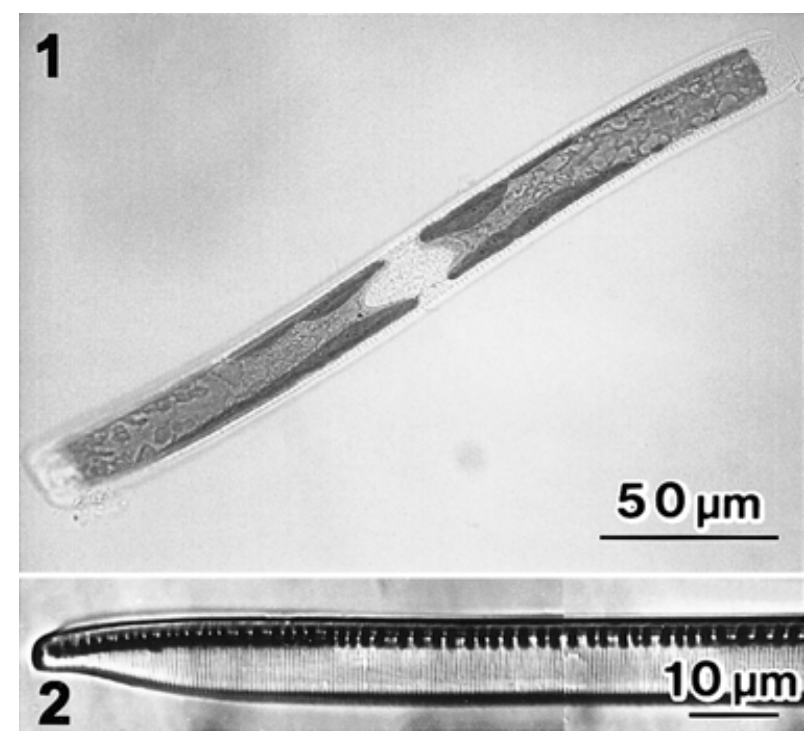

Figs 1,2. Nitzschia sigmoidea. 1. Living cell in girdle view, showing two elongated plate-like chloroplasts along the apical axis. 2. Valve of cleaned specimen in valve view.

\section{TEM observations}

Cells were fixed with $1 \%$ glutaraldehyde in PBS for $5 \mathrm{~s}$, then post-fixed with $0.2 \% \mathrm{OsO}_{4}$ in $\mathrm{PBS}$ for $15 \mathrm{~min}$ at $4^{\circ} \mathrm{C}$. After washing three times with the same buffer, they were embedded in an agar block, then dehydrated in a graded series of ethanol. The block was embedded in Spurr's resin and polymerized for $8 \mathrm{~h}$ at $70^{\circ} \mathrm{C}$. Sections were cut on an ultramicrotome using a diamond knife, stained with uranyl acetate and Reynold's lead citrate, then examined by TEM.

For immunoelectron microscopy, cells were fixed with $1 \%$ glutaraldehyde for $1 \mathrm{~h}$. After washing, they were embedded in an agar block, then dehydrated in graded ethanol and acetone series. The block was embedded in Quetol 812 and polymerized for $36 \mathrm{~h}$ at $60^{\circ} \mathrm{C}$. Ultra-thin sections $100 \mathrm{~nm}$ thick on formvarcoated nickel grids were treated with $3 \%$ hydrogen peroxide for $5 \mathrm{~min}$, with $1 \%$ BSA for $1 \mathrm{~h}$ at room temperature, then with the solution of antibody raised against the large subunit of Rubisco on a shaker for $8 \mathrm{~h}$ at $10^{\circ} \mathrm{C}$. After rinsing with PBS containing $0.05 \%$ Tween-20, they were treated with protein A-gold ( $E Y$ Laboratories, San Matteo, CA, USA) for $1 \mathrm{~h}$ at room temperature then rinsed with PBS. After staining with $3 \%$ uranyl acetate for $15 \mathrm{~min}$, the sections were observed by TEM.

\section{RESULTS}

The cells collected were sigmoid in girdle view and 200-275 $\mu \mathrm{m}$ long. As in most Nitzschia species, each single cell had two chloroplasts, which were located on opposite sides of the central nucleus along the longitudinal axis (Fig. 1). The valves were linear with acute

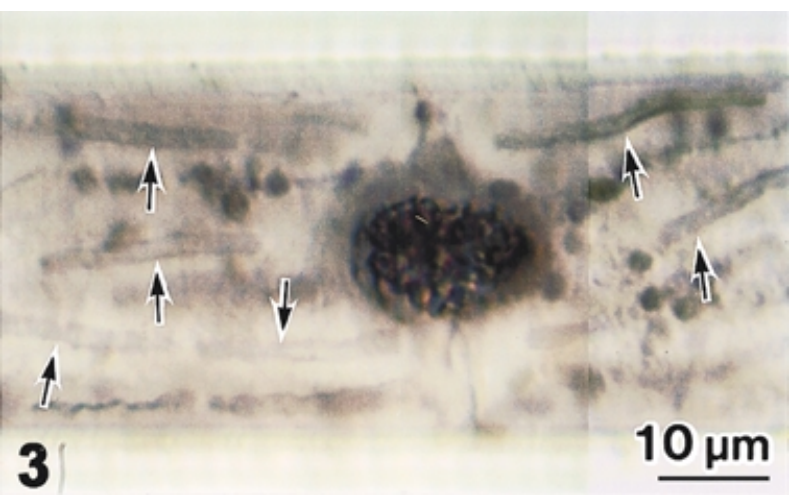

Fig. 3. Details of cell center, showing rod-shaped structures stained with propionocarmine (arrows). The dark oval structure is the nucleus.

apices, and 8.5-10.0 $\mu \mathrm{m}$ wide (Fig. 2). There were 24-25 striae and approximately six fibulae in $10 \mu \mathrm{m}$. We identified this species as $N$. sigmoidea, based on the fact that these features agreed well with a diatom described frequently in Europe (e.g. Krammer \& LangeBertalot 1988); and despite its large size, this species had not previously been recorded in Japan before 1993 when we first found it in a river. There were many research reports on river diatoms in Japan, but none of them recorded N. sigmoidea (e.g. Kobayasi 1964; Mayama \& Kobayasi 1982; Negoro \& Goto 1983; Kobayasi et al. 1985; Watanabe et al. 1986; Kitazawa \& Kobayasi 1988; Tokyoto Kankyo Hozenkyoku Suishitsuhozenbu 1996, 1997), and none were found in ponds either.

With the light microscope, we could not observe the linear-oblong structures that Geitler (1937) saw in non-stained cells, but these structures could be observed in cells stained with propionocarmine (Fig. 3). The length of each structure was approximately $10 \mu \mathrm{m}$, and the width approximately $1 \mu \mathrm{m}$. In each structure, the peripheral part was stained darker than the mid-portion.

Epifluorescence microscopy showed many pairs of parallel DAPI-fluorescent lines throughout the chloroplast (Fig. 4a). No DAPI fluorescence was observed along the edge of the chloroplast (Fig. $4 \mathrm{~b}$ ). The average length of each pair was $15.8 \mu \mathrm{m}$ during interphase (min. $10 \mu \mathrm{m}$, max. $21 \mu \mathrm{m}, n=20$ cells), and the distance between each fluorescent line was stable and approximately $1.2 \mu \mathrm{m}$, which corresponds to the width of pyrenoid stained by propionocarmine. Diffused pale DAPI fluorescence observed in the mid-portion of the cell (Fig. 4b) was mitochondrial DNA, which could be distinguished from $\mathrm{cp}$-DNA because they were observed as fine particles in monochrome photographs (Fig. 5).

Based on the fact that the pairs of DAPI fluorescent lines disappeared after DNase treatment (Fig. 6), it was confirmed that these lines contained DNA. Though 

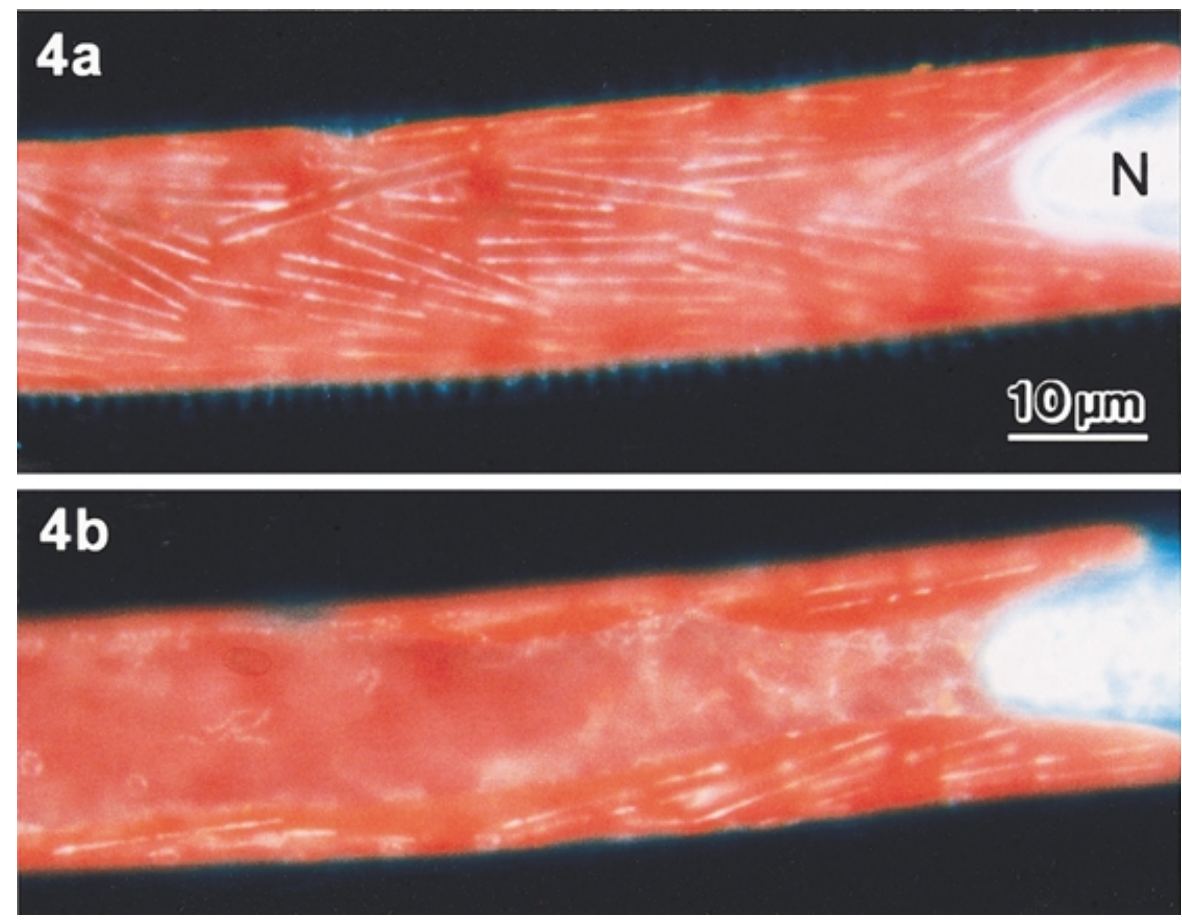

Fig. 4. Epifluorescence microscopy of DAPI-stained cell in girdle view. (a) and (b) were taken of the same specimen but in different focal planes. N, nucleus. (a) Many pairs of parallel fluorescent lines are scattered throughout the chloroplast; here the focus was on the main body of the chloroplast. (b) Along the edge of the chloroplast, no chloroplast nucleoid was detected. Diffused pale DAPI fluorescence along the midline of the cell indicates mitochondrial DNA.
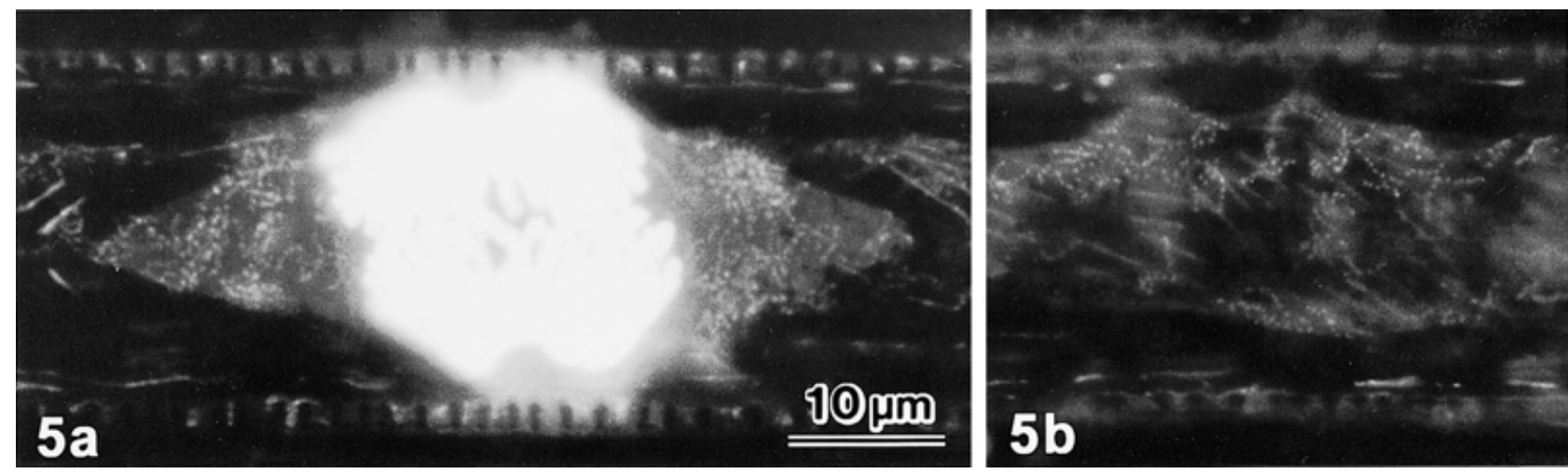

Fig. 5. Epifluorescence microscopy of DAPI-stained dividing cell in girdle view, showing fine fluorescent particles of mitochondrial DNA. (a) Chromosomes at anaphase are visible in the center of the cell. (b) An area a short distance from the center.
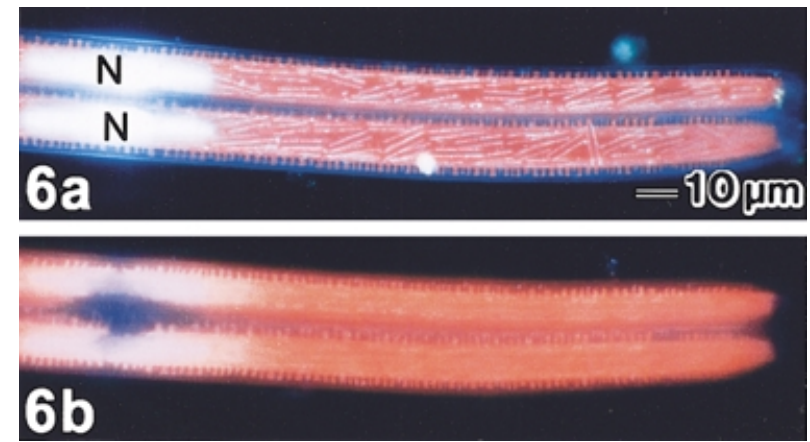

Fig. 6. DAPI-stained cells. (a) Sibling cells before addition of DNase. N, nucleus. (b) The same cells after incubation for $3 \mathrm{~h}$ with DNase, showing the disappearance of the double lines of DAPI fluorescence within the chloroplasts and marked reduction of fluorescence in the nuclei. there was still residual fluorescence from the nuclei in Fig. $6 \mathrm{~b}$ because of the abundance of DNA in this region, it entirely disappeared after a further $2 \mathrm{~h}$ in DNase.

Although the distance between the pairs of DNAcontaining lines was stable even during chloroplast division, the average length of these pairs decreased to $3.8 \mu \mathrm{m}$ (min. $1 \mu \mathrm{m}$, max. $6 \mu \mathrm{m}, n=20$ cells), which was about one-quarter of that in interphase, and the number of pairs doubled synchronously (Fig. 7a,b). By the completion of the sibling valves, the length had been restored (Fig. 7c,d).

Each cell section embedded in technovit showed three to six sites of FITC fluorescence after anti-Rubisco antibody staining, indicating the presence of Rubisco (Fig. 8a, arrowhead). Additional staining with DAPI in the same section showed six to 12 DNA-containing 

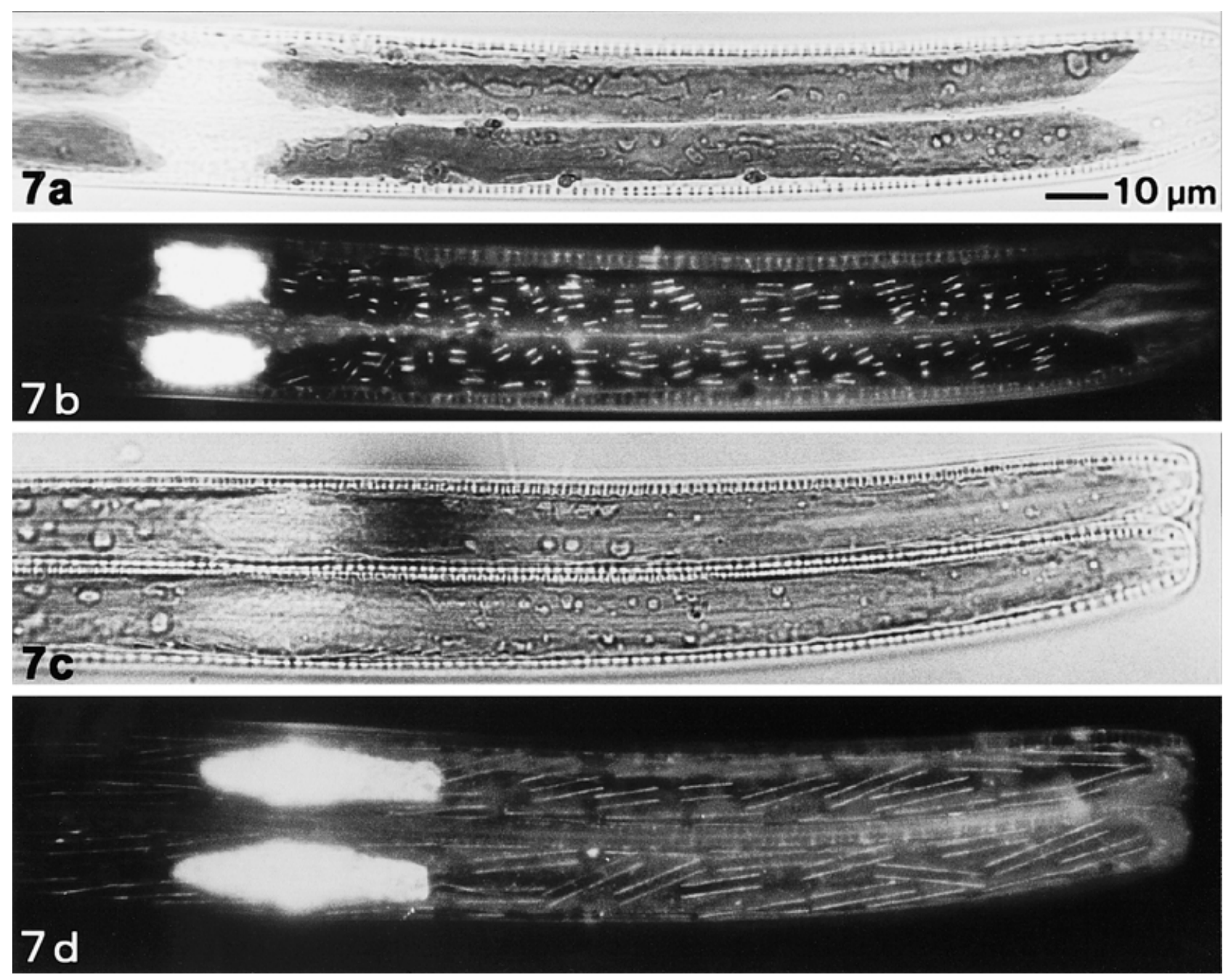

Fig. 7. Fluctuation in the number and length of DNA-containing lines during the cell cycle. (a) Telophase cell. (b) The same specimen as (a), but epifluorescence microscopy. The pairs of DAPI-fluorescent lines reduced in length. (c) Sibling cells after new valve formation. (d) The same specimen as (c), but epifluorescence microscopy. The DAPI-fluorescent lines have recovered their lengths.

dots in chloroplasts (Fig. 8b, arrowheads). These dots were located on both sides of the FITC fluorescent sites, but not on the margins of chloroplasts (Fig. 8c).

In the cross section of the cell, TEM showed six to 10 lanceolate or fusiform structures in a chloroplast (Figs 9,10). These structures had an insertion of a single thylakoid (Figs 10,11). On both sides of the structures, there were opaque areas (Fig. 11) in which several electron-dense fibrils per section were observed under high magnification (Fig. 12, arrowheads). The immunoelectron microscopy revealed deposits of gold particles on the lanceolate structure, indicating the localization of Rubisco in this structure (Fig. 13), though gold particles are rarely observed on the matrix of the chloroplast.

\section{DISCUSSION}

Studies of the diatom pyrenoids have been mainly focused on their shape, number and fine structure. The 'typical' diatom pyrenoid, which has been observed with TEM by many authors, is lanceolate to fusiform in profile with insertion of one to several thylakoids, for example, N. palea (Drum 1963), Achnanthes minutissima Kütz., Cyclotella meneghiniana Kütz. Surirella ovalis Bréb. (Drum \& Pankratz 1964), Neidium affine (Ehrenb.) Pfitzer (Drum et al. 1966), Lithodesmium undulatum Ehrenb. (Manton \& von Stosch 1966), Melosira varians C. Agardh (Crawford 1973), Diatoma vulgaris Bory (Pickett-Heaps et al. 1975) and Navicula cuspidata (Kütz.) Kütz. (Edgar \& Pickett-Heaps 1983). The linear structures with lanceolate to fusiform profile in the chloroplasts of $N$. sigmoidea are conclusively pyrenoids, though they are unusually linear-oblong in shape and scattered throughout the chloroplast. While similar shapes and scattering were described to be pyrenoids based on light microscopic observations in several genera (see Mann 1996), our results confirm a brief previous description (Mayama et al. 1998) and some figures (Schmidt 2001). 

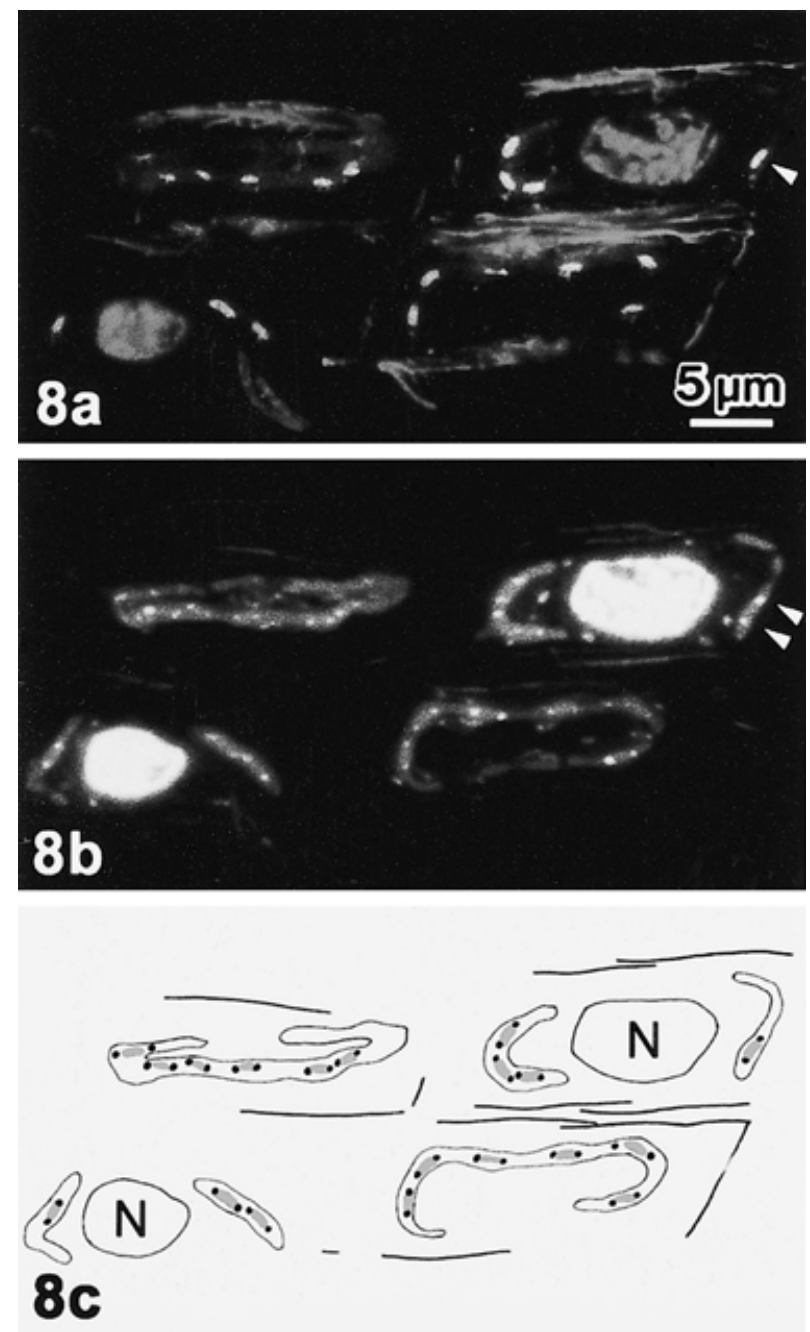

Fig. 8. Fluorescein isothiocyanate (FITC) (a, arrowhead) and DAPI ( $b$, arrowheads) fluorescence, indicating the positions of Rubisco and DNA, respectively, in cross sections of chloroplasts of four cells. (a) Because of high-contrast development, the fluorescence of FITC absorbed non-specifically and partly into the frustules and nuclei was also enhanced. (b) Images of chloroplasts are obscurely visible. (c) Tracings from (a) and (b) overlaid. N, nucleus.

In our study, the pyrenoid was immunolabeled by the antibody raised against the cucumber Rubisco, which may show that these structures are physiologically pyrenoids. However, we have to be careful in accepting this conclusion, because there have been suggestions that the Rubisco of diatoms is structurally different from the Rubiscos of Euglena, Chlamydomonas and land plants, based on immunological reactions with anti-Rubisco antibodies (Plumley et al. 1986). In addition, the similarity of chrysophycean Rubisco to red alga Rubisco, but its difference from that of spinach, has been reported (Newman et al. 1989). These differences can be easily understood, given the phylogeny of the chloroplast genes (Grzebyk et al. 2003). Nevertheless, our results with the antibody should be accepted because Orellana and Perry (1992), employing a Western blot, showed that anti-
Rubisco anti-serum purified from Chaetoceros gracilis Schütt (Bacillariophyceae) reacted positively with the Rubiscos of 38 species from Cyanophyta, Cryptophyceae, Crysophyceae, Haptophyta, Eustigmatophyceae, Bacillariophyceae, Dinophyta, Chlorophyta, Euglenophyta, Phaeophyceae, Rhodophyta and spinach. Using dot blots, they indicated that the affinity of the anti-serum and the binding strength differed among species. They also showed by Western blot and enzyme-linked immunosorbent assay (ELISA) that the active site of the Rubisco was similar among Chaetoceros, Phaeodactylum (Bacillariophyceae), Isochrysis (Haptophyta), Olisthodiscus (Raphidophyceae) and Dunaliella (Chlorophyta). Therefore, the fact that the anti-Rubisco antiserum made from cucumber recognized the pyrenoid of $N$. sigmoidea could be due to the high density and affinity of the antibodies in the anti-serum. It is probably for the same reason that, despite using an anti-serum from the pea (Pisum sp.), Schmidt (2003b) recently showed a photograph of rhombic pyrenoids of $N$. sigmoidea in immunofluorescence microscopy, though the contradiction between the affinity and phylogeny was not discussed because $N$. sigmoidea was only used as a control in the Rubisco assay.

It is known that the chloroplast nucleoid of diatoms is usually arranged in a ring along the margin of the chloroplast (Coleman 1979, 1985; Kuroiwa et al. 1981), and this characteristic is shared by some other heterokontophyte classes and also the Bolidophyceae, which is the sister group to the diatoms in 18S rDNA and $r b c L$ analyses (Guillou et al. 1999; Daugbjerg \& Guillou 2001). In contrast to this, scattered chloroplast nucleoids are distributed in some other, relatively minor groups of heterokontophytes, that is, Dictyochophyceae (Moestrup \& Thomsen 1990), Eustigmatophyceae (Coleman 1985), Pedinellophyceae (Throndsen 1971; Patterson \& Fenchel 1985; Patterson 1986; Koutoulis et al. 1988), Pelagophyceae (Andersen et al. 1993), Sarcinochrysidales (O'Kelly 1989), and even a species of Xanthophyceae (Miyamura \& Hori 1991). In addition to the ring nucleoid, however, Mayama and Shihira-Ishikawa (1994) found DNA-containing dots scattered throughout the chloroplast in Pinnularia nobilis (Ehrenb.) Ehrenb., and pointed out that these dots were also putative nucleoids. Similar dots were recently explained as endobacteria invaginated into the chloroplast during interphase, which seemed to have been domesticated by the host Pinnularia (Schmidt 2003a). However, we have never observed such endobacteria even in interphase, and are carrying out further examinations. In N. sigmoidea, DNA was not detected along the margin of the chloroplasts either in whole cells or in sectioned cells stained with DAPI; it was detected only on both sides of the linear-oblong pyrenoids. Furthermore, by TEM, a genophore, which is the area containing the ring nucleoid, lying just beneath the girdle lamella was not observed in this study. 


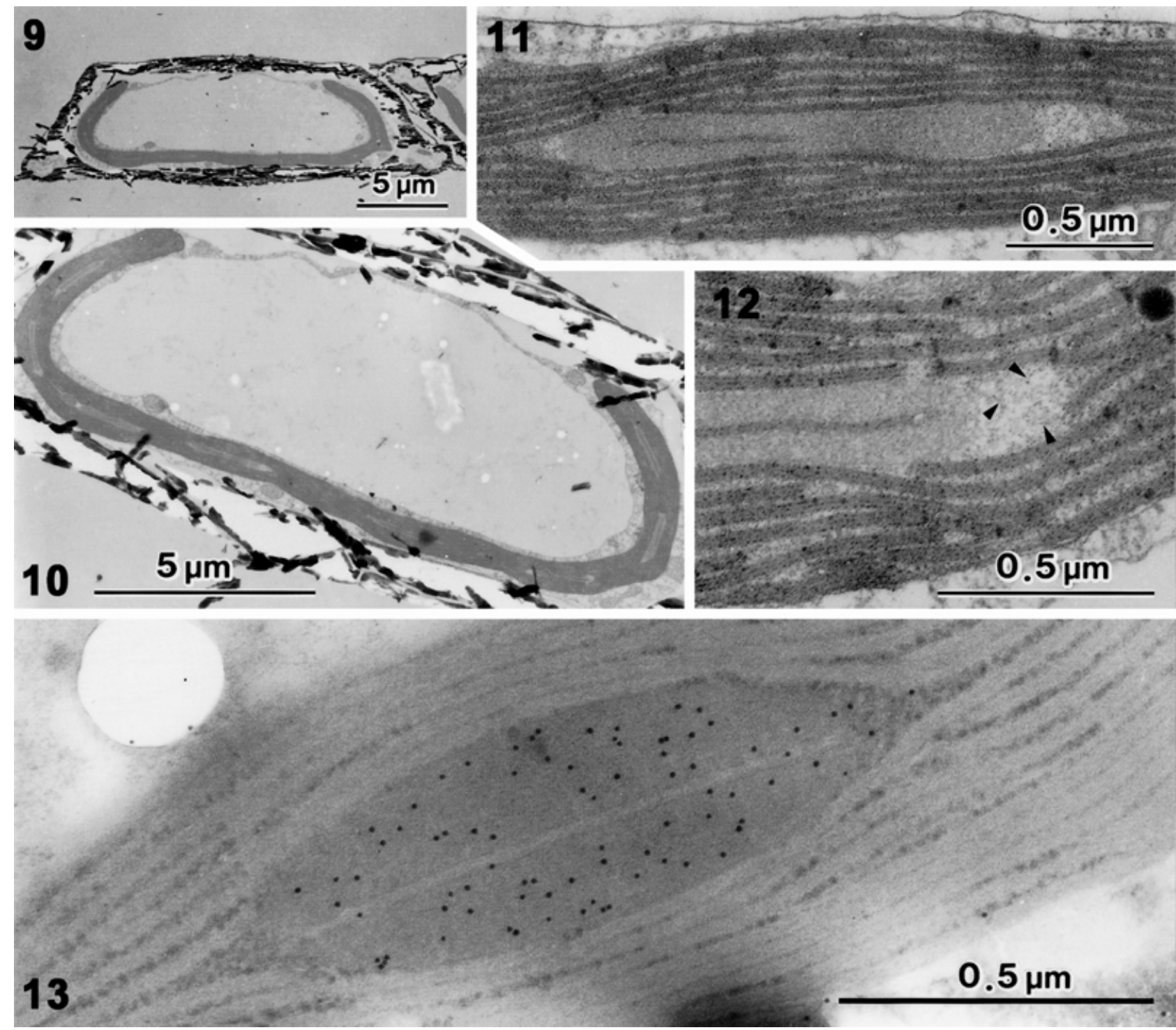

Figs 9-13. Transmission electron microscopy. 9. Cell with a single chloroplast showing hantzschioid symmetry. 10. Single chloroplast with eight narrowly lanceolate structures. 11. One thylakoid is inserted in the narrow pyrenoid with electron opaque areas on both sides. 12. The opaque area containing several electron-dense fibrils (arrowheads). 13. Immunogold particles on the lanceolate pyrenoid indicating localization of Rubisco.

In some algae, cp-DNA has been observed as electron-dense fibrils by TEM (Ris \& Plaut 1962; Bisalputra \& Bisalputra 1969). In diatoms, however, the fibrils are scarcely recognizable in most TEM photographs published, except for several excellent figures by, for example, Manton and von Stosch (1966) or Manton et al. (1969). The fibrils observed on the small areas of both sides of the pyrenoids of $N$. sigmoidea were considered to be DNA because their locations coincide with the profile images of the immunofluorescence microscopy combined with DAPI staining.

The DNA zones on both sides of the pyrenoids in $N$. sigmoidea are synchronously divided during chloroplast division, and they seem to function as the substantial chloroplast nucleoid. Kuroiwa et al. (1981) classified the distribution patterns of chloroplast nucleoids into five types: namely, the SN-type which is characterized by chloroplasts with small, uniformly dispersed $\mathrm{cp}$-nucleoids; the $\mathrm{CN}$-type, which is characterized by chloroplasts with one or a few $\mathrm{cp}$-nucleoids located in the central area of the chloroplst; the CLtype, which has chloroplasts with a large ring-shaped $c p$-nucleoid inside the girdle lamellae; the SP-type, which has numerous small cp-nucleoids forming a shell around a pyrenoid in the chloroplast; and the PStype, which is characterized by chloroplasts with $\mathrm{cp}$ nuclei scattered along their peripheries. Miyamura and Hori $(1989,1991)$ reported an additional type, in which DNA was incorporated into the pyrenoid itself, but the distribution pattern seen in $N$. sigmoidea cannot be assigned to any of these classifications. 
Nitzschia sigmoidea is the type species of the genus Nitzschia Hassall, which is one of the largest genera among diatoms, and its characteristics are very important to define the genus. As far as we know, other Nitzschia species have a ring nucleoid; this applies even to Nitzschia vermicularis (Kütz.) Hantzsch (our unpubl. data, 1996), which has a valve structure and sigmoid girdle view similar to that of $N$. sigmoidea. However, several valve characteristics, chloroplast arrangement, and a type of auxospore formation in $N$. sigmoidea are shared by the other Nitzschia species (Mann 1986), which ensures that the current circumscription of the taxonomic group is retained. Thus, the unique character state of the cp-nucleoid in $N$. sigmoidea should be considered an autapomorphy. Rather, it indicates that this species is a potential source for elucidation of a mechanism to design the various configurations of the $c p$-nucleoid among algae.

Another remark is due here to the distribution of $N$. sigmoidea. This species had been previously absent in Japan, but after its discovery in 1993 in Saitama Prefecture, its habitat expanded to many rivers in Chiba Prefecture (Idei et al. 1998) and Nara Prefecture; and presently, it occurs also in various rivers in the Tokyo Metropolitan area and its surrounding prefectures (our unpubl. data, 2000). Interestingly, this immigration was often accompanied by $N$. vermicularis, which had not previously been recorded in Japan either (Idei et al. 1998). Similar naturalizations at the end of the 20th century were reported in Achnanthidium pyrenaicum (Hust.) H. Kobayasi and Cyclotella shanxiensis Xie et Qi (Ishida \& Kobayasi 1996). Substantial records concerning diatom transfer are very rare, so this example of $N$. sigmoidea deserves to be described for the study of the distribution mechanism of microalgae associated with bird migration and climate change as well as foreign trade.

Given that the number of diatom species is estimated to be between 10000 and 100000 (Hasle \& Syvertsen 1996) or approximately 200000 (Mann \& Droop 1996; Mann 1999), and that the number of diatom genera described is over 1000 (Fourtanier \& Kociolek 1999), diatoms are the most divergent organisms among algae. Although the diversity of diatoms has been studied mainly based on valve morphology, the results of our study support the view expressed elsewhere (e.g. Cox 1981; Mann 1996; Schmidt 2001) that analyses of the diversity of plastid and pyrenoid structures will be useful for obtaining a better understanding of relationships among diatoms. We can now add a further source of characters, namely, the physical organization of the plastid genome.

\section{ACKNOWLEDGMENTS}

We would like to thank $\mathrm{Dr}$ Toshihide Ohya and $\mathrm{Dr}$ Shinichi Miyamura (University of Tsukuba) for offering the rubisco-specific antibody. Thanks are also due to Dr Tomoko Ehara (Tokyo Medical University) for the immunoelectron microscopy. This research was partly supported by grants from the Ministry of Education, Science and Culture of Japan (No. 07304082 and 06804056).

\section{REFERENCES}

Andersen, R. A., Saunders, G. W., Packind, M. P. and Sexton, J. P. 1993. Ultrastructure and 18S rRNA gene sequence for Pelagomonas calceolata gen. et sp. nov. and the description of a new algal class, the Pelagophyceae classis nov. J. Phycol. 29: 701-15.

Archibald, R. E. M. and Barlow, D. J. 1983. On the raphe ledge in the genus Amphora (Bacillariophyta). Bacillaria 6: 257-66.

Bisalputra, T. and Bisalputra, A. A. 1969. The ultrastructure of chloroplast of a brown alga Sphacelaria sp. 1. Plastid DNA configuration - the chloroplast genophore. J. Ultrastruc. Res. 29: 151-70.

Coleman, A. W. 1979. Use of fluorochrome 4'6-diamidino-2phenylindole in genetic and developmental studies of chloroplast DNA. J. Cell Biol. 82: 299-305.

Coleman, A. W. 1985. Diversity of plastid DNA configuration among classes of eukaryote algae. J. Phycol. 21: 1-16.

Coombs, J., Lauritis, J. A., Darley, W. M. and Volcani, B. E. 1968. Studies on the biochemistry and fine structure of silica shell formation in diatoms. V. Effects of colchicines on wall formation in Navicula pelliculosa (Bréb.) Hilse. Z. Pflanzenphysiol. 59: 124-52.

Cox, E. J. 1981. The use of chloroplasts and other features of the living cell in the taxonomy of Naviculoid diatoms. In Ross, R. (Ed.) Proceedings of the Sixth Symposium on Recent and Fossil Diatoms. O. Koeltz, Koenigstein, pp. 115-33.

Cox, E. J. 1996. Identification of Freshwater Diatoms from Live Material. Chapman and Hall, London, 158 pp.

Crawford, R. M. 1973. The protoplasmic ultrastructure of the vegetative cell of Melosira varians C. A. Agardh. J. Phycol. 9: 50-61.

Crawford, R. M. 1981. Some considerations of size reduction in diatom cell walls. In Ross, R. (Ed.) Proceedings of the Sixth Symposium on Recent and Fossil Diatoms. O. Koeltz, Koenigstein, pp. 253-65.

Daugbjerg, N. and Guillou, L. 2001. Phylogenetic analyses of Bolidophyceae (Heterokontophyta) using $r b c L$ gene sequences support their sister group relationship to diatoms. Phycologia 40: 153-61.

Dawson, P. A. 1973. Observations on the structure of some forms of Gomphonema parvulum Kütz. II. The internal organization. J. Phycol. 9: 165-75.

Drum, R. W. 1963. The cytoplasmic finer structure of the diatom Nitzschia palea. J. Cell Biol. 18: 429-40.

Drum, R. W. and Pankratz, H. S. 1964. Pyrenoids, raphes, and other fine structures in diatoms. Am. J. Bot. 51: 405-18. 
Drum, R. W., Pankratz, R. W. and Stoermer, E. F. 1966. Electron microscopy of diatom cells. In Helmcke, J.-D. and Krieger, W. (Eds) Diatomeenschalen im elektronenmikroskopischen Bild. Teil VI. J. Cramer, Lehre, pp. 1-24, pls 514-613.

Edgar, L. A. 1980. Fine structure of Caloneis amphisbaena (Bacillariophyceae). J. Phycol. 16: 62-72.

Edgar, L. A. and Pickett-Heaps, J. D. 1983. The mechanism of diatom locomotion. I. Proc. Royal Soc. London B. 218: 331-43.

Fourtanier, E. and Kociolek, J. P. 1999. Catalogue of the diatom genera. Diat. Res. 14: 1-190.

Geitler, L. 1926. Zur Morphologie und Entwicklungsgeschichte der Pyrenoide. Arch. Protistenkd. 56: 128-44.

Geitler, L. 1937. Der Chromatophorenbau der Diatomeen Gyrosigma attenuatum und Nitzschia sigmoidea. Beih. Bot. Cbl. 57/A: 425-31.

Geitler, L. 1959. Morphologische, entwicklungsgeschichtliche und systematische Notizen über einige Süsswasseralgen. Österr. Bot. Z. 106: 159-71.

Geitler, L. 1975. Lebendbeobachtung der Chromatophorenteilung der Diatomeen. Nitzschia. Pl. Syst. Evol. 123: 145-52.

Geitler, L. 1981. Die Lage des Chromatophors in Beziehung zur systematic von Cymbella-Arten (Bacillariophyceae). PI. Syst. Evol. 136: 275-86.

Grzebyk, D., Schofield, O., Vetriani, C. and Falkowski, P. G. 2003. The Mesozoic radiation of eukaryotic algae: the portable plastid hypothesis. J. Phycol. 39: 259-67.

Guillou, L., Chrétiennot-Dinet, M.-J., Medlin, L. K., Claustre, H., Goër, S. L. and Vaulot, D. 1999. Bolidomonas: a new genus with two species belonging to a new algal class, the Bolidophyceae (Heterokonta). J. Phycol. 35: 368-81.

Hasle, G. R. and Syvertsen, E. E. 1996. Marine diatoms. In Tomas, C. R. (Ed.) Identifying Marine Diatoms and Dinoflagellates. Academic Press, San Diego, pp. 5-385.

Heinzerling, 0. 1908. Der Bau der Diatomeenzelle mith besonderer Berucksichtigung der ergatischen Gebilde und der Beziehung des Baues zur Systematik. Bibl. Bot. 69: 1-88.

Idei, M., Mayama, S. and Nagumo, T. 1998. Bacillariophyceae. In Chihara, M. (Ed.) Natural History of Chiba Prefecture 4. Plants in Chiba. 1. Bacteria, Fungi, Lichen, Algae and Bryophytes. Chiba Historical Material Resarch Foundation, Chiba, pp. 344-77 (in Japanese).

Ishida, N. and Kobayasi, H. 1996. Three diatom species newly found in Japan and their occurrence in the Inabegawa (Inabe River) and Tama-gawa (Tama River), Central Japan. Diatom 12: 27-33 (in Japanese).

Jenks, A. and Gibbs, S. P. 2000. Immunolocalization and distribution of Form II Rubisco in the pyrenoid and chloroplast stroma of Amphidinium carterae and Form I Rubisco in the symbiont-derived plastids of Peridinium foliaceum (Dinophyceae). J. Phycol. 36: 127-38.

Karsten, G. 1899. Die Diatomeen der Kieler Bucht. Wiss. Meeresunters. N. F. Kiel 4: 17-205.

Kerby, N. W. and Evans, L. V. 1978. Isolation and partial characterization of pyrenoids from the brown alga Pilayella littoralis (L.) Kjellm. Planta 142: 91-5.
Kitazawa, S. and Kobayasi, H. 1988. Diatoms and water quality in the upper Chikuma River. Bull. Tokyo Gakugei Univ. Sect. 4: 91-117 (in Japanese).

Kobayasi, H. 1964. Diatoms from River Arakawa (2). Bull. Chichibu Mus. Nat. Hist. 1964: 65-77 (in Japanese).

Kobayasi, H. and Mayama, S. 1982. Most pollution-tolerant diatoms of severely polluted rivers in the vicinity of Tokyo. Jpn J. Phycol. 30: 188-96.

Kobayasi, H., Mayama, S., Asai, K. and Nakamura, S. 1985. Occurrence of diatoms collected from variously polluted rivers in Tokyo and its vicinity, with special reference to the correlation between relative frequency and $\mathrm{BOD}_{5}$. Bull. Tokyo Gakugei Univ. Sect. 4: 21-46 (in Japanese).

Koutoulis, A., McFadden, G. I. and Wetherbee, R. 1988. Spinescale reorientation in Apedinella radians (Pedinellales, Chrysophyceae): The microarchitecture and immunocitechemistry of the associated cytoskeleton. Protoplasma 147: 25-41.

Krammer, K. and Lange-Bertalot, H. 1988. Bacillariophyceae. 2. Teil. Bacillariaceae, Epithemiaceae, Surirellaceae. In Ettl, H., Gerloff, J., Heynig, H. and Mollenhauer, D. (Eds) Süsswasserflora von Mitteleuropa, vol. 2. Gustav Fischer, Stuttgart, 596 pp.

Kuchitsu, K., Tsuzuki, M. and Miyachi, S. 1988. Characterization of the pyrenoid isolated from unicellular green alga Chlamydomonas reinhardtii: particulate form of RUBISCO protein. Protoplasma 144: 17-24.

Kuroiwa, H. 1991. The application of the Technovit embedding method for the research of plant embryology. Plant Morph. 3: 43-7.

Kuroiwa, T., Suzuki, T., Ogawa, K. and Kawano, S. 1981. The chloroplast nucleus: distribution, number, size, and shape, and a model for the multiplication of the chloroplast genome during chloroplast development. Plant Cell Physiol. 22: 381-96.

Lacoste-Royal, G. and Gibbs, S. P. 1987. Immunocytochemical localization of ribulose-1,5-bisphosphate carboxylase in the pyrenoid and thylakoid region of the chloroplast of Chlamydomonas reinhardtii. Plant Physiol. 83: 602-6.

Lauterborn, R. 1896. Untersuchungen Über Bau, Kernteilung und Bewegung der Diatomeen. W. Engelmann, Leipzig, $165 \mathrm{pp}$.

Li, C. W. and Volcani, B. E. 1985. Studies on the biochemistry and fine structure of silica shell formation in diatoms. VIII. Morphogenesis of the cell wall in a centric diatom, Ditylum brightwellii. Protoplasma 124: 10-29.

Mann, D. G. 1984. Protoplast rotation, cell division and frustule symmetry in the diatom Navicula bacillum. Ann. Bot. 53: 295-302.

Mann, D. G. 1986. Nitzschia subgenus Nitzschia (Notes for a monograph of the Bacillariaceae 2). In Ricard, M. (Ed.) Proceedings of the 8th International Diatom Symposium. O. Koeltz, Koenigstein, pp. 215-26.

Mann, D. G. 1996. Chloroplast morphology, movements and inheritance in diatoms. In Chaudhary, B. R. and Agrawal, S. B. (Eds) Cytology, Genetics and Molecular Biology of Algae. SPB Academic Publishing, Amsterdam, pp. 249-74. 
Mann, D. G. 1999. The species concept in diatoms. Phycologia 38: 437-95.

Mann, D. G. and Droop, S. J. M. 1996. Biodiversity, biogeography and conservation of diatoms. Hydrobiologia 336: 19-32.

Manton, I., Kowallik, K. and von Stosch, H. A. 1969. Observations on the fine structure and development of the spindle at mitosis and meiosis in a marine centric diatom (Lithodesmium undulatum). II. The early meiotic stages in male gametogenesis. J. Cell Sci. 5: 271-98.

Manton, I. and von Stosch, H. A. 1966. Observations on the fine structure of the male gamete of the marine centric diatom Lithodesmium undulatum. J. R. Microsc. Soc. 85: 119-34.

Mayama, S. and Kobayasi, H. 1982. Diatoms from the Aonogawa River. Bull. Tokyo Gakugei Univ. Sect. 4: 77-107 (in Japanese).

Mayama, S., Mayama, N. and Shihira-Ishikawa, I. 1998. Rodshaped pyrenoids with chloroplast DNA and arranged along both sides in Nitzschia sigmoidea. 15th International Diatom Symposium. Diatom Research and Australasian Association of Diatom Researchers, Curtin University of Technology, Western Australia, p. 55.

Mayama, S. and Shihira-Ishikawa, I. 1994. Putative nucleoids scattered in chloroplast of Pinnularia nobilis (Bacillariophyceae). Jpn J. Phycol. 42: 437-41.

McKay, R. M. L. and Gibbs, S. P. 1991. Composition and function of pyrenoids: Cytochemical and immunocytochemical approaches. Can. J. Bot. 69: 1040-52.

McKay, R. M. L., Lichtlé, C. and Gibbs, S. P. 1992. Immunocytochemical characterization of the intrapyrenoid thylakoids of cryptomonads. J. Phycol. 28: 64-8.

Mereschkowsky, C. 1902. Les types de l'endochrome. Scripta Bot. Hort. Univ. Petropolit. 21: 1-193.

Mitrophanow, P. 1898. Beobachtungen über Diatomeen. Flora 85: 293-314.

Miyamura, S. and Hori, T. 1989. Presence of DNA in the pyrenoid matrix of the siphonous green alga, Caulerpa okamurae Web. V. Bos. Plant Morph. 1: 19-22.

Miyamura, S. and Hori, T. 1991. DNA is present in the pyrenoid core of the siphonous green algae of the genus Caulerpa and yellow-green algae of the genus Pseudodichotomosiphon. Protoplasma 161: 192-6.

Moestrup, Ø. and Thomsen, H. A. 1990. Dictyocha speculum (Silicoflagella, Dictyochophyceae), studies on armoured and unarmoured stages. Biol. Skrifter 37: 1-57.

Morita, E., Kuroiwa, H., Kuroiwa, T. and Nozaki, H. 1997. High localization of ribulose-1, 5-bisphosphate carboxylase/oxygenase in the pyrenoids of Chlamydomonas reinhardtii (Chlorophyta), as revealed by cryofixation and immunogold electron microscopy. J. Phycol. 33: 68-72.

Negoro, K. and Gotoh, T. 1983. Diatom vegetation of the River Yura. Mem. Fac. Agr. Kinki Univ. 16: 67-118 (in Japanese).

Newman, S. M., Derocher, J. and Cattolico, R. A. 1989. Analysis of chromophytic ribulose-1,5-bisphosphate carboxylase indicates extensive structural and functional similarities among evolutionarily diverse algae. Plant Physiol. 91: 939-46.

Nishibayashi, S. and Kuroiwa, T. 1982. Behavior of leucoplast nucleoids in the epidermal cell of onion (Allium cepa) bulb. Protoplasma 110: 177-84.

O'Kelly, C. J. 1989. The evolutionary origin of the brown algae: information from studies of motile cell ultrastructure. In Green, J. G., Leadbeater, B. S. C. and Diver, W. L. (Eds) The Chromophyte Algae: Problems and Perspectives. Systematics Association Special Volume no. 38. Clarendon Press, Oxford, pp. 255-78.

Ohya, T. and Shimazaki, K. 1989. Profiles of proteins in guard-cell and mesophyll protoplasts from Vicia faba L. fractionated by sodium dodecylsulfate-polyacrylamide gel electrophoresis. Plant Cell Physiol. 30: 783-7.

Orellana, M. V. and Perry, M. J. 1992. An immunoprobe to measure RUBISCO concentrations and maximal photosynthetic rates of individual phytoplankton cells. Limnol. Oceanogr. 37: 478-90.

Orellana, M. V. and Perry, M. J. 1995. Optimization of an immunofluorescent assay of the internal enzyme ribulose1,5-bisphosphate carboxylase (RUBISCO) in single phytoplankton cells. J. Phycol. 31: 785-94.

Osafune, T., Yokota, A., Sumida, S. and Hase, E. 1990. Immunogold localization of ribulose-1,5-bisphosphate carboxylase with reference to pyrenoid morphology in chloroplasts of synchronized Euglena gracilis cells. Plant Physiol. 92: 802-8.

Patterson, D. J. 1986. The actinophryid heliozoa (Sarcodina, Actinopoda) as Chromophytes. In Kristiansen, J. and Andersen, R. A. (Eds) Chrisophytes: Aspects and Problems. Cambridge University Press, Cambridge, pp. 49-67.

Patterson, D. J. and Fenchel, T. 1985. Insights into the evolution of Heliozoa (Protozoa, Sarcodina) as provided by ultrastructural studies on a new species of flagellate from the genus Pteridomonas. Biol. J. Linn. Soc. 34: 381-403.

Pickett-Heaps, J. D., McDonald, K. and Tippit, D. H. 1975. Cell division in the pennate diatom Diatoma vulgare. Protoplasma 86: 205-42.

Plumley, F. G., Kirchman, D. L., Hodson, R. E. and Schmidt, G. W. 1986. Ribulose bisphosphate carboxylase from three chlorophyll c-containing algae. Plant Physiol. 80: 685-91.

Ris, H. and Plaut, W. 1962. Ultrastructure of DNA-containing areas in the chloroplast of Chlamydomonas. J. Cell Biol. 13: 383-91.

Rosowski, J. R. and Hoshaw, R. W. 1970. Staining algal pyrenoids with carmine after fixation in an acidified hypochlorite solution. Stain Tech. 45: 293-8.

Salisbury, J. L. and Floyd, G. L. 1978. Molecular, enzymatic and ultrastructure characterization of the pyrenoid of the scaly green monad Micromonas squamata. J. Phycol. 14: 362-8.

Satoh, H., Okada, M., Nakayama, K. and Miyaji, K. 1984. Purification and further characterization of pyrenoid proteins and ribulose-1,5-bisphosphate carboxylase-oxygenase from the green alga Bryopsis maxima. Plant Cell Physiol. 25: 1205-14. 
Schmidt, A. M. 2001. Value of pyrenoids in the systematics of the diatoms: their morphology and ultrastructure. In Economou-Amilli, A. (Ed.) Proceedings of the 16th International Diatom Symposium. University of Athens Press, Athens, pp. 1-32.

Schmidt, A. M. 2003a. Endobacteria in the diatom Pinnularia (Bacillariophyceae). I. 'Scattered ct-nucleoids' explained: DAPI-DNA complexes stem from exoplastidal bacteria boring into the chloroplasts. J. Phycol. 39: 122-38.

Schmidt, A. M. 2003b. Endobacteria in the diatom Pinnularia (Bacillariophyceae). II. Host cell cycle-dependent translocation and transient chloroplast scars. J. Phycol. 39: 139-53.

Schmitz, F. 1882. Die Chromatophoren der Algen. Verh. D. Naturhist, Verh. D. Preuss., Rheinl. U. Westf. 40: 1-180.

Schmitz, F. 1884. Beiträge zur Kentinis der Chromatophoren. Jahrb. F. Wiss. Bot. 15: 1-177.

Thaler, F. 1972. Beitrag zur Entwicklunsgeschichte und zum Zellbau einiger Diatomeen. Österr. Bot. Z. 120: 313-47.

Throndsen, J. 1971. Apedinella gen. nov. and the fine structure of $A$. spinifera (Throndsen) comb. nov. Norw. J. Bot. 18: 47-64.
Tokyoto Kankyo Hozenkyoku Suishitsuhozenbu. 1996. Comprehensive analyses of aquatic organisms, no. 1. Fluctuated Data of the Water Quality and Aquatic Organisms for the Past 15 Years of a Metropolitan Area River. 1. Water Quality Protection Division of Tokyo Metropolitan Government, Tokyo, 324 pp. (in Japanese).

Tokyoto Kankyo Hozenkyoku Suishitsuhozenbu. 1997. Comprehensive analyses of aquatic organisms, no. 2. Fluctuated Data of the Water Quality and Aquatic Organisms for the Past 15 Years of a Metropolitan Area River. 2. Water Quality Protection Division of Tokyo Metropolitan Government, Tokyo, 369 pp. (in Japanese).

Tschermak-Woess, E. 1953. Über auffallende Strukturen in den Pyrenoiden einiger Naviculoideen. Österr. Bot. Z. 100: 160-78.

Watanabe, T., Asai, K., Houki, A., Tanaka, S. and Hizuka, T. 1986. Saprophilous and eurysaprobic diatom taxa to organic water pollution and diatom assemblage index (DAlpo). Diatom 2: 23-73. 
This document is a scanned copy of a printed document. No warranty is given about the accuracy of the copy. Users should refer to the original published version of the material. 